\title{
Dwarf mistletoes as a relevant component in temperate forest: an integral view
}

\begin{abstract}
Dwarf mistletoes are considered harmful parasites of temperate forests. However, different studies found that they contribute positively to ecosystem functioning and enhance diversity in the forest community. This mini-review attempts to highlight the importance of dwarf mistletoes in temperate forests, based on case studies of pine forests in central Mexico. We emphasize the complexity of the infection dynamics, and how it can be modified by human activities. We propose that dwarf mistletoes should be seen as an integral part of forests.
\end{abstract}

Keywords: Arceuthobium, diversity, ecosystem benefits, host-interactions, key role, parasitic plants

\author{
Volume 2 Issue I - 2018
}

\author{
Mónica E Queijeiro-Bolaños,' Zenón Cano- \\ Santana ${ }^{2}$ \\ 'Facultad de Ciencias Naturales, Universidad Autónoma de \\ Querétaro, Mexico \\ ${ }^{2}$ Facultad de Ciencias, Universidad Nacional Autónoma de \\ México, Mexico
}

\author{
Correspondence: Zenón Cano-Santana, Departamento \\ de Ecología y Recursos Naturales, Facultad de Ciencias, \\ Universidad Nacional Autónoma de México, Ciudad \\ Universitaria, 045 I0 Mexico City, Mexico,Tel +00 52555622 \\ 4835,Email zcs@ciencias.unam.mx
}

Received: February 14, 2018 | Published: February 23, 2018

\section{Introduction}

Dwarf mistletoes (Arceuthobium spp.; Viscaceae) are parasitic plants widely distributed in North American temperate forests, where 39 of the 47-known species are distributed. ${ }^{1}$ These plants are found parasitizing mainly trees of the Pinaceae family, although it has been registered on some Cupressaceae individuals. ${ }^{1}$ These plants have been marked as harmful parasites of temperate forests, because of the deleterious effects they can cause. ${ }^{2}$ These effects are caused because dwarf mistletoes attach themselves to the hosts' trunk or branches through a special organ, the haustorium, which function as a modified root system that extracts water and mineral nutrients from the host xylem. ${ }^{3}$ The latter causes a reduction in growth and fecundity, branch and stem deformations, high water stress and poor water use efficiency, and, in extreme cases, the death of the host. ${ }^{3}$ The Mexican territory, is considered a center of diversity for the genus, since 22 species are distributed along the country, associated with the large forest areas, ${ }^{1}$ and it is considered as the second most serious cause of forest damage, causing an annual loss of $2.0 \times 10^{6} \mathrm{~m}^{3}$ of round wood. ${ }^{4}$

However, the economic losses are measured in how much timber cannot be used because the tree would not produce a desirable quality wood. The latter may lead to high grading practices, where a selective harvest of the best quality timber is done, leaving behind the trees in poor conditions. ${ }^{5}$ These practices are not recommended by foresters, however, when applied, is because mistletoes are seen as a negative part of the ecosystems. Nonetheless, recent approaches are showing that mistletoes are an important part of the ecosystems, and are considered as a keystone resource. ${ }^{6,7}$ Watson $\mathrm{D}^{6}$ found on a review that at least 97 vertebrate families use mistletoes for food, and other 50 for nesting sites. ${ }^{6}$ Other studies show the great presence of arthropods, ${ }^{8-10}$ mammals and birds ${ }^{6}$ on mistletoes, where some interactions are very specific, such as the one of the Patagonian marsupial Dromiciops gliroides with Tristerix corimbosus. ${ }^{11}$ Even more, when mistletoes are present in an ecosystem nutrients turnover to the soil is faster and leaf litter is richer in nutrients. ${ }^{12,13}$

We have been studying different ecological aspects of the two most widely spread species of dwarf mistletoes in Mexican temperate forests: Arceuthobium vaginatum subsp. vaginatum and A. globosum subsp. grandicaule; the first one is distributed from the north of the country to the central part, and the second from the southern region (even including some parts of Guatemala) to the central part, where it come together with $A$. vaginatum ${ }^{1}$ in the Trans-Mexican volcanic belt, where Pinus hartwegii (the Mexican mountain pine) is very common and serve as host for both species ${ }^{4}$. There is concern about these dwarf mistletoes species, since $P$. hartwegii is a species of economic importance. ${ }^{14}$

\section{Discussion}

From our research, we dare to say that pines are not being as negatively affected, and that this interaction can enhance diversity in temperate forests, something that has been registered for other parasitic plants. ${ }^{15}$ Moreover, the population dynamics of dwarf mistletoes is very complex. For instance, when these two species coexist on the same tree, $A$. vaginatum tend to be on the lower parts of the tree (mostly below $1.7 \mathrm{~m}$ ); whereas $A$. globosum is distributed from 0.1 to $5.0 \mathrm{~m} .{ }^{16}$ The latter suggests that these species have a differential use if the resource. Besides, they have a complex infection dynamics where self-regulation is strong, limiting its own population growth and allowing a stable coexist among the two species; however, both species can experience competition or facilitation with each other, depending on the size of the tree and the homogeneity of the forest, where a low-density homogenous stand may promote a facilitation process between the two species. ${ }^{17}$ This has management implications, as it suggests that system simplification can enhance dwarf mistletoes parasitism. 
Dwarf mistletoe infection depends on several factors, both biotic and abiotic, where altitude and slope define its distribution, ${ }^{17,18}$ and host availability affects their prevalence (incidence and severity) as well as an aggregated distribution pattern. ${ }^{19}$ Mostly, the prevalence is strongly affected by stand structure and hosts' size, as there is a clear preference for hosts with greater diameter and crown cover as well as there is a positive correlation with pines density, being more frequent in denser stands that are in regeneration process. ${ }^{19,20}$ However, different disturbance factors can influence their incidence, such as waste deposits, logging and fire incidence. ${ }^{18}$ Fire incidence seems to be a natural way to control dwarf mistletoes, and population sizes of these two species fluctuate in response to fires. ${ }^{17,21}$

The above shows that dwarf mistletoe ecology is complex, and many factors should be considered. In our studies on the effect on pines growth, there is no significant difference between the relative diameter growth rate between the non-infected and infected trees. ${ }^{20}$ However, there was a significant effect on trees' allometric (diameterheight) relationship: infected trees tend to be shorter at the same diameter than uninfected trees. ${ }^{20}$ This effect may not be harmful for pines' fitness, although this still needs corroboration.

These mistletoes have numerous interactions with arthropods, since we found 30 morpho species living on A. globosum, 35 on $A$. vaginatum, and 40 on the pine, being especially abundant the members of Prostigmata, Thysanoptera and Homoptera. ${ }^{22}$ Dwarf mistletoes provide shelter to many microarthropods, and these can be fulfilling an important role in the ecosystem, such as pollination and decomposition. ${ }^{23}$ There are also other complicated interactions that need further research, such as the possible facilitation with the resin butterfly, ${ }^{24}$ that also parasite $P$. hartwegii.

\section{Conclusion}

Dwarf mistletoes' infection dynamics is complex and is governed by biotic and abiotic factors; however, although normally seen as a harmful parasite, it is an important part of the ecosystem improving diversity and ecosystem processes, which possibly derivates in more benefits than detriments. This dynamic can be altered by anthropogenic activities, such as logging or non-adequate management practices. Hence, we recommend that dwarf mistletoes should have a more integrative focus, acknowledging its key role in communities and ecosystems.

\section{Acknowledgements}

None.

\section{Conflict of interest}

The authors declare that they have no conflict of interests.

\section{References}

1. Hawksworth FG, Wiens D. Dwarf Mistletoes: Biology, Pathology, and Systematics. Department of Agriculture Forest Service. USA: 1996. 410 p.

2. Geils BW, Hawksworth FG. Damage, effects, and importance of dwarf mistletoes. In: Geils BW, Tovar JC, Moody B, editors. Mistletoes of North American Conifers. USA: USDA Forest Service General Technical Report; 2002:57-66.

3. Mathiasen RL, Shaw DC, Nickrent D, et al. Mistletoes: Pathology, systematics, ecology, and management. Plant Disease. 2008; 92(7):9881006.
4. Cibrián D, Vázquez I, Cibrián J. Muérdagos enanos del género Arceuthobium. In: Cibrián D, Alvarado D, García S, editors. Enfermedades forestales en México. Mexico:Universidad Autónoma de Chapingo; 2007:357-395.

5. Nyland RD. Silviculture: Concepts and Applications. USA: Waveland Press; 2016.

6. Watson D. Mistletoe - a keystone resource in forests and woodlands worldwide. Annual Review of Ecology and Systematics. 2001;32(1):219249 .

7. Watson DM, Herring M. Mistletoe as a keystone resource: an experimental test. Proceedings of the Royal Society B. 2012;279:3853-3860.

8. Whittaker PL. The insect fauna of mistletoe (Phoradendron tomentosum, Loranthaceae) in southern Texas. Southwestern Naturalist. 1984;29(4):435-444.

9. Burns AE, Cunningham SA, Watson D. Arthropod assemblages in tree canopies: a comparison of orders on box mistletoe (Amyema miquelii) and its host eucalypts. Austral Entomology. 2011;50(3):221-230.

10. Anderson SJ, Braby MF. Invertebrate diversity associated with tropical mistletoe in a suburban landscape from northern Australia. Northern Territory Naturalist. 2009;21:2-23.

11. Amico G, Aizen MA. Ecology: Mistletoe seed dispersal by a marsupial. Nature.2000;408(6815):929-930.

12. March WA, Watson D. The contribution of mistletoes to nutrient returns : evidence for a critical role in nutrient cycling. Austral Ecology. 2010;35(7):713-721.

13. Ndagurwa H, Dube JS, Mlambo D. The influence of mistletoes on nutrient cycling in a semi-arid savanna, southwest Zimbabwe. Plant Ecology. 2014;215(1):15-26.

14. Musálem MA, Solís MA. Monografía de Pinus hartwegii. Mexico: INIFAP; 2000.

15. Press MC, Phoenix GK. Impacts of parasitic plants on natural communities. The New Phytologist. 2005;166(3):737-751.

16. Queijeiro-Bolaños ME, Cano-Santana Z, Castellanos-Vargas I. Distribución diferencial de dos especies de muérdago enano sobre Pinus hartwegii en el área natural protegida 'Zoquiapan y anexas', Estado de México. Acta Botanica Mexicana. 2011;96:49-57.

17. Queijeiro-Bolaños ME, González EJ, Martorell C, et al. Competition and facilitation determine dwarf mistletoe infection dynamics. Journal of Ecology. 2017;105(3):775-785.

18. Queijeiro-Bolaños ME, Cano-Santana Z, Castellanos-Vargas I. Does disturbance determines the prevalence of dwarf mistletoe (Arceuthobium, Santalales: Viscaceae) in Central Mexico? Revista Chilena de Historia Natural. 2013;86:181-190.

19. Queijeiro-Bolaños ME, Cano-Santana Z, García-Guzmán G. Incidence, severity, and aggregation patterns of two sympatric dwarf mistletoe species (Arceuthobium spp.) in Central Mexico. European Journal of Forest Research. 2014;133(2):297-306.

20. Queijeiro-Bolaños ME, Cano-Santana Z. Growth of hartweg's pine (Pinus hartwegii) parasitized by two dwarf mistletoe species (Arceuthobium spp.). Botanical Sciences. 2016;94(1):51-62.

21. Oseguera TK. Efecto del disturbio por tala sobre la intensidad de la infestación por Arceuthobium vaginatum en Zoquiapan, Estado de Méxic, México. BSc Thesis. Mexico: Universidad Nacional Autónoma de México; 2017.

22. Queijeiro-Bolaños ME, Cano-Santana Z. Dinámica temporal de la infestación por muérdago enano (Arceuthobium globosum y $A$ vaginatum) en Zoquiapan (Parque Nacional Iztaccíhuatl Popocatépetl), México. CienciaUAT. 2015;9(2):6-14. 
23. Chávez-Salcedo LF, Queijeiro-Bolaños ME, López-Gómez V, et al. Contrasting arthropod communities associated with dwarf mistletoes Arceuthobium globosum and A. vaginatum and their host Pinus hartwegii. Journal of Forestry Research. 2017:1-14.
24. Navarrete-Alfonzo A. Asociación del muérdago enano (Arceuthobium spp.) y la mariposa resinera (Synanthedon cardinalis) en Pinus hartwegii de Zoquiapan, Estado de México, México. BSc Thesis. Mexico: Universidad Nacional Autónoma de México; 2017. 